\title{
PENGUKURAN PENJUMLAHAN INTENSITAS DUA SUMBER CAHAYA PADA VARIASI DAYA LAMPU MENGGUNAKAN LIGHTMETER
}

\author{
Rizky Bayu Kurniawan, Yudhiakto Pramudya \\ Program Studi Magister Pendidikan Fisika, Universitas Ahmad Dahlan \\ Email: yudhiakto.pramudya@pfis.uad.ac.id
}

Diterima: 06 Januari 2021. Direvisi: 22 Februari 2021. Disetujui: 15 Maret 2021.

\begin{abstract}
Abstrak
Konsep perubahan intensitas cahaya terhadap jarak memerlukan metode pengukuran yang memberikan ketepatan dalam menghasilkan data. Aplikasi lightmeter pada smartphone digunakan dalam penelitian ini untuk mengukur penjumlahan intensitas cahaya (I) dari dua sumber cahaya. Daya lampu divariasikan untuk mendapatkan data intensitas cahaya pada jarak dan daya lampu yang berbeda. Intensitas cahaya untuk ketiga variasi adalah 6,2746 Cd dan 5,8546 Cd, 9,8808 Cd dan 9,6650 Cd, serta 12,8302 dan 11,9215. Nilai tersebut setara dengan iluminasi $(E)$ sebesar 32,59671 lux dan 26,964 lux, 51,3220 lux dan 44,9105 lux, serta 43,9934 lux dan 37,1495 lux. Hasil dari intensitas cahaya dan iluminasi yang diperoleh pada ketiga variasi daya lampu berbanding terbalik dengan kuadrat jaraknya. Semakin jauh lightmeter diletakan dari sumber cahaya, nilai intensitas cahaya dan iluminasinya semakin kecil. Hal ini sesuai hukum keterbalikan kuadrat pada hukum fisika yang menyatakan sumber pancaran berbanding terbalik dengan kuadrat jaraknya.
\end{abstract}

Kata Kunci: Intensitas cahaya, Iluminasi, Lightmeter.

\begin{abstract}
The concept of light intensity changes with respect to distance requires a measurement method that provides accuracy in producing data. The lightmeter application on a smartphone is used in this study to measure the sum of light intensity (I) of two light sources. The lamp power was varied to obtain the light intensity data at different distances and lamp power. The light intensity for the three lamp power variations are $6.2746 \mathrm{Cd}$ and 5.8546 $\mathrm{Cd}, 9.8808 \mathrm{Cd}$ and $9.6650 \mathrm{Cd}$, and 12.8302 and 11.9215. Those values are equivalent to the illumination (E) of 32.59671 lux and 26.964 lux, 51.3220 lux and 44.9105 lux, and 43.9934 lux and 37.11495 lux. The results of the intensity of light and illumination obtained in the three power lamp variations are inversely proportional to the square of the distance. The farther the lightmeter is placed from the light source, the smaller the value of light intensity and illumination. It is suitable to the law of inverted squares which states that the source of the emission is inversely proportional to the square of the distance.
\end{abstract}

Keywords: Light intensity, Illumination, Lightmeter. 
Kurniawan., Pramudya. - Pengukuran Penjumlahan Intensitas...

\section{PENDAHULUAN}

Cahaya merupakan salah satu komponen yang penting dalam menunjang kehidupan manusia (Saputra \& Nurdiah, 2013). Para siswa dianjurkan untuk memahami dan mempelajari terkait komponen tersebut (Nurfarida, Yusup, \& Komariah, 2017).

Konsep cahaya sangat penting dalam mempelajari astronomi. Proses pemahaman konsep cahaya dapat diterapkan dalam pembelajaran fisika di sekolah. Namun pemahaman konsep tersebut terkadang tidak mudah dipahami oleh siswa. Sehingga perlu digunakan alat peraga untuk mempelajari tentang konsep cahaya khususnya intensitas cahaya yang diukur pada permukaan model Bola Bumi (Sukmawati \& Pramudya, 2019).

Setiap sumber cahaya memiliki intensitas yang berbeda antara satu dengan yang lainnya. Intensitas cahaya (I) merupakan fluks cahaya persatuan sudut (Afriyani, Surantoro, \& Supurwoko, 2019). Candela (Cd) merupakan satuan dari intensitas cahaya (Rahman, 2016). Penentuan nilai intensitas cahaya didahului dengan mencari iluminasi $(E)$ dari sumber cahaya. Iluminasi merupakan jumlah cahaya dari sumber tertentu dengan satuannya adalah lux (Hasanah \& Nurdiawati, 2017). Besarnya iluminasi cahaya perlu diketahui karena pada dasarnya manusia memerlukan pencahayaan yang cukup (Rahmadiansyah et al. 2017).

Pengukuran nilai iluminasi dapat dilakukan menggunakan photometer. Alat photometer merupakan salah satu alat yang dapat digunakan untuk mengukur intensitas cahaya (Herdiwijaya, 2016). Pada tahap awal akan digunakan photometer yang dibuat dari kertas noktah berminyak. Penggunaan photometer bertujuan untuk menemukan titik semi transparan pada kedua buah sumber cahaya. Sehingga pada titik tersebut, iluminasi kedua sumber cahaya berada pada nilai yang sama. Sebagai penguat data iluminasi maka digunakan lightmeter.

Lightmeter merupakan alat untuk mengukur iluminasi pada sumber cahaya (Wu et al. 2018). Lightmeter yang digunakan dalam pengukuran berbasis pada aplikasi di smartphone. 
Kurniawan., Pramudya. - Pengukuran Penjumlahan Intensitas...

Penggunaan smartphone untuk tambahan pada penelitian. Kedua mengukur iluminasi sudah dapat sumber tersebut akan divariasikan dilakukan dengan akurat (Gutierrez, menjadi tiga bagian sesuai dengan 2017). Hal ini dikarenakan dayanya. Sehingga akan diperoleh smartphone memiliki kemampuan hasil yang cukup akurat tentang fungsional Personal Computer intensitas cahaya pada dua sumber (Sudin, Djufri, \& Umar, 2020). cahaya.

Sehingga pengukuran iluminasi sebagai dasar untuk memperoleh intensitas cahaya dapat dilaksanakan.

Tujuan dari penelitian ini adalah untuk mengetahui nilai intensitas cahaya dari dua buah sumber cahaya. Pada penelitian sebelumnya digunakan satu sumber cahaya (Zelviani \& Albar, 2018). Secara teknis pada penelitian ini berinovasi pada penggunaan dua sumber cahaya. Kemudian penggunaan photometer dan lightmeter akan menjadi inovasi

\section{METODE}

Penelitian ini menggunakan metode eksperimen untuk mengukur intensitas cahaya. Alat dan bahan yang digunakan dalam penelitian ini yaitu lampu berdaya 15 watt dan 25 watt, photometer, lightmeter pada smartphone (Phyphox), laptop, alat peraga intensitas cahaya. Adapun tampilan alat peraga dan lightmeter pada smartphone (Phyphox) seperti pada gambar 1 .

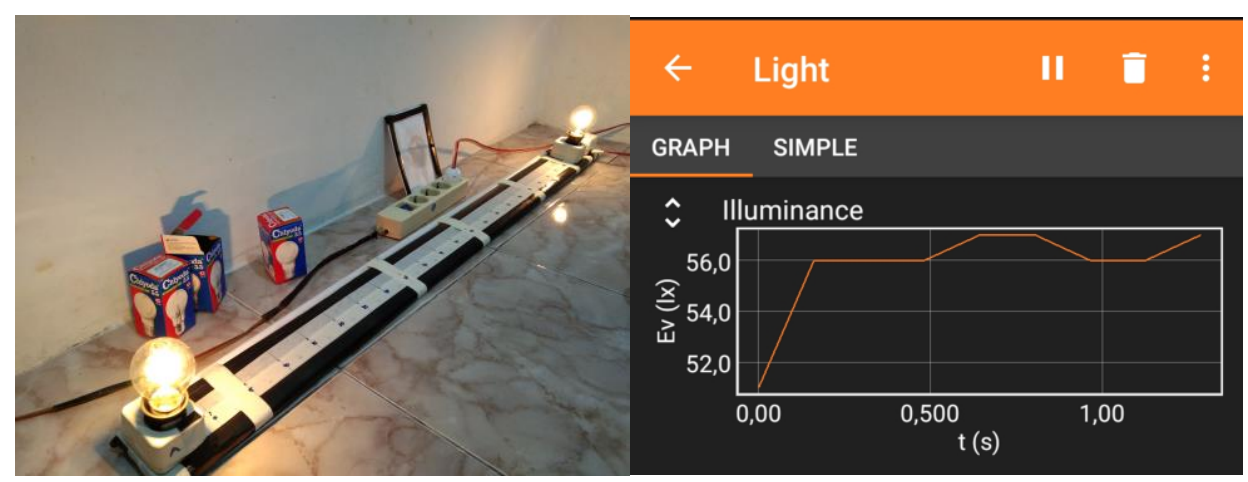

Gambar 1. Alat Peraga Intensitas Cahaya dan Lightmeter pada smartphone

Pengambilan data pada tahap menentukan dua sumber cahaya pertama dilakukan dengan cara dengan tiga jenis variasi. Penentuan 
Kurniawan., Pramudya. - Pengukuran Penjumlahan Intensitas ...

variasi daya lampu adalah 15 watt dan 15 watt, 25 watt dan 25 watt, serta 15 watt dan 25 watt. Pemilihan daya lampu didasarkan pada ketersediaan yang dapat dibeli. Panjang lintasan antara kedua buah sumber cahaya adalah $100 \mathrm{~cm}$.

Tahap selanjutnya yaitu penentuan titik semi transparan pada kertas photometer. Titik semi transparan ini terjadi ketika noktah berminyak pada kertas mulai tidak terlihat. Penentuan titik ini dilakukan untuk kedua buah sumber cahaya.

Setelah titik tengah $(x)$ antara dua sumber cahaya (lampu bohlam) ditemukan menggunakan photometer (Kertas noktah berminyak). Selanjutnya ditentukan titik minimum $(x-10 \mathrm{~cm})$ dan maksimumnya $(x+10$ $\mathrm{cm})$. Titik atau jarak yang diperoleh menggunakan photometer pada variasi dua sumber cahaya terdapat pada tabel 1 .

Tabel 1. Titik Semi Transparan Photometer

\begin{tabular}{ccc}
\hline No. & Variasi daya lampu & Titik semi transparan $(\mathbf{c m})$ \\
\hline 1. & 15 watt dan 15 watt & 45 \\
2. & 25 watt dan 25 watt & 45 \\
3. & 15 watt dan 25 watt & 55 \\
\hline
\end{tabular}

Tahap kedua yang dilakukan dengan cara mengukur iluminasi (lux) menggunakan lightmeter pada smartphone. Data yang terukur pada lightmeter di-input langsung pada laptop yang telah disediakan. Pengukuran dilakukan pada setiap titik atau jarak, yang dimulai dari titik minimum hingga maksimumnya.

Pengukuran dilakukan bergantian pada satu variasi dengan mematikan salah satu lampunya. Kemudian dilakukan bergantian untuk lampu lain pada setiap variasinya. Kemudian titik semi transparan pada lightmeter dapat diperoleh menggunakan persamaan (1) dan (2) berikut:

$y_{1}=a x_{1}^{2}+b x_{1}+c$

$y_{2}=d x_{2}^{2}+e x_{2}+f$

$y_{1}$ dan $y_{2}$ merupakan intensitas cahaya. Keduanya bernilai sama $\left(y_{1}=y_{2}\right) \quad$ ketika nilai $x=x_{1}=x_{2}$. Nilai $a, b, c, d, e$, dan $f$ merupakan konstanta yang diperoleh dari perpotongan kurva dari jarak dan 
Kurniawan., Pramudya. - Pengukuran Penjumlahan Intensitas ...

iluminasi yang diperoleh dari

lightmeter. Persamaan (1) dan (2)

dioperasikan hingga diperoleh

persamaan 3 berikut:

$\alpha x^{2}+\beta x+\gamma=0$

Melalui persamaan (3), kita dapat mengetahui bahwa $\alpha=a-d$, $\beta=b-e \operatorname{dan} \gamma=e-f . \quad$ Langkah selanjutnya yaitu menghitung akar dari persamaan (3) menentukan nilai $x$ yang menjadi titik tengah antara kedua lampu. Hal ini dibutuhkan untuk menentukan titik ketika intensitas antara kedua lampu bernilai sama. Oleh karena itu, diperoleh persamaan (4) sebagai berikut:

$x=\frac{-\beta \pm \sqrt{\beta^{2}-4 \alpha \gamma}}{2 \alpha}$

Penentuan intensitas cahaya berasal dari data iluminasi yang diperoleh. Secara matematis, iluminasi dan intensitas cahaya dapat dituliskan seperti pada persamaan berikut:

$$
\begin{aligned}
& I=E r^{2} \\
& E=\frac{I}{r^{2}}
\end{aligned}
$$

Perolehan data tentang iluminasi dan intensitas cahaya akan dilihat hubungannya dengan jarak yang telah ditentukan.

\section{HASIL DAN PEMBAHASAN}

Hasil dan pembahasan pada penelitian ini adalah sebagai berikut:

\section{Hasil}

Proses pengambilan data pada tiga jenis variasi sumber daya lampu. Percobaan pertama dilakukan dengan variasi daya pada $L_{1 A}=15$ watt dan $\mathrm{L}_{2 \mathrm{~A}}=15$ watt. Diperoleh titik semi transparan untuk kedua buah lampu, yaitu sebesar $45 \mathrm{~cm}$. Batas minimumnya sebesar $35 \mathrm{~cm}$ dan batas maksimumnya sebesar $55 \mathrm{~cm}$. Oleh karena itu, diperoleh data percobaan seperti pada tabel 2 .

Tabel 2. Jarak (x) dan Iluminasi $(E)$

\begin{tabular}{cccc}
\hline \multirow{2}{*}{ No. } & \multirow{2}{*}{ Jarak (cm) } & $\mathbf{L}_{\mathbf{1 A}}$ & $\mathbf{L}_{\mathbf{2 A}}$ \\
\cline { 3 - 4 } & 35 & 44,849088 & 21,98373 \\
1. & 40 & 37,136855 & 23,52708 \\
2. & 45 & 31,523021 & 26,19980 \\
3. & 50 & 26,898316 & 30,10147 \\
4. & 55 & 22,576096 & 33,00828 \\
5. & & & \\
\hline
\end{tabular}


Kurniawan., Pramudya. - Pengukuran Penjumlahan Intensitas ...

Setelah diketahui nilai iluminasi kurva pada kedua sumber cahaya, pada dua buah sumber cahaya lampu. seperti pada gambar 2 berikut:

Selanjutnya ditentukan titik potong

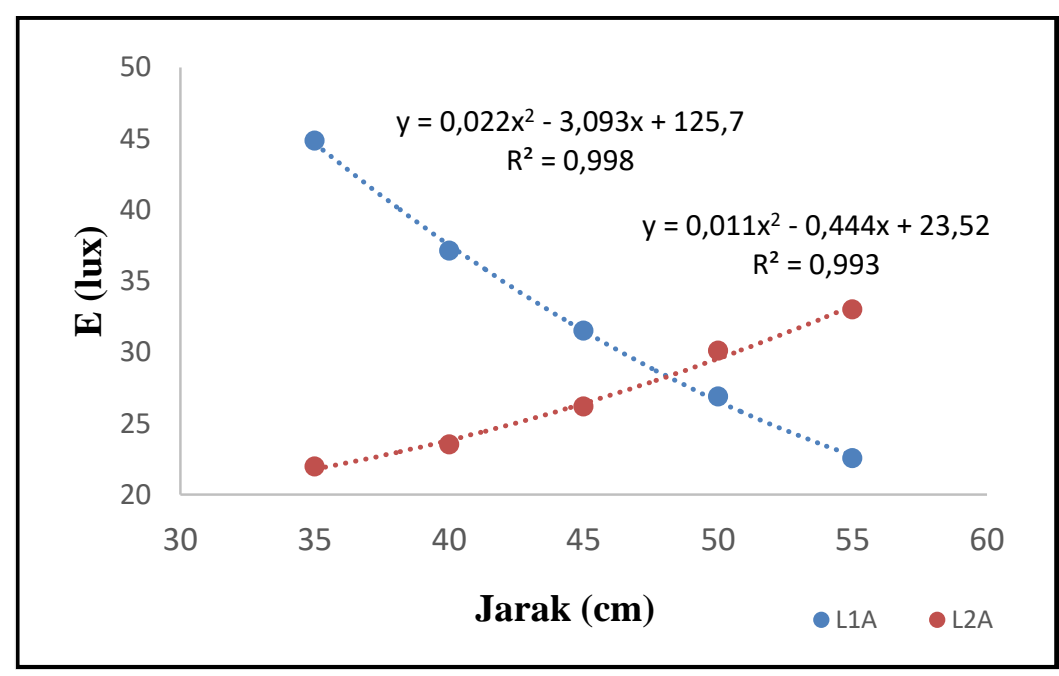

Gambar 2. Hubungan Jarak dan Iluminasi

Persamaan (3) dan (4) digunakan digunakan untuk memperoleh untuk menemukan titik semi intensitas cahaya dan iluminasi. Hasil transparan pada lightmeter. Oleh perolehan intensitas cahaya dan karena itu, diperoleh $x=48,1193 \mathrm{~cm}$. iluminasi pada $\mathrm{L}_{1 \mathrm{~A}}$ dan $\mathrm{L}_{2 \mathrm{~A}}$, Selisih pada kertas lightmeter dan ditunjukan seperti pada tabel 3 photometer adalah $3,1193 \mathrm{~cm}$. berikut:

Sedangkan, persamaan (5) dan (6) pada hukum keterbalikan kuadrat,

Tabel 3. Intensitas Cahaya (I) dan Iluminasi $(E)$

\begin{tabular}{llcccc}
\hline \multirow{2}{*}{ No. } & \multirow{2}{*}{$\mathbf{r}^{\mathbf{2}}(\mathbf{m})$} & \multicolumn{2}{c}{ Intensitas Cahaya $(\boldsymbol{I})$} & \multicolumn{2}{c}{ Iluminasi $(\boldsymbol{E})$} \\
\cline { 3 - 6 } & & \multicolumn{1}{c}{$\mathbf{L}_{\mathbf{1 A}}$} & $\mathbf{L}_{\mathbf{2 A}}$ & $\mathbf{L}_{\mathbf{1 A}}$ & $\mathbf{L}_{\mathbf{2 A}}$ \\
\hline 1. & 0,1225 & 5,49401 & 2,69300 & 44,84909 & 21,98373 \\
2. & 0,16 & 5,94189 & 3,76433 & 37,13686 & 23,52708 \\
3. & 0,2025 & 6,38341 & 5,30545 & 31,52302 & 26,1998 \\
4. & 0,25 & 6,72457 & 7,52536 & 26,89832 & 30,10147 \\
5. & 0,3025 & 6,82926 & 9,98500 & 22,5761 & 33,00828 \\
\hline \multicolumn{2}{c}{ Rata-rata } & $\mathbf{6 , 2 7 4 6}$ & $\mathbf{5 , 8 5 4 6}$ & $\mathbf{3 2 , 5 9 6 7}$ & $\mathbf{2 6 , 9 6 4 1}$ \\
\hline
\end{tabular}


Kurniawan., Pramudya. - Pengukuran Penjumlahan Intensitas...

Tabel 3 menunjukkan perolehan nilai intensitas cahaya dan nilai iluminasinya. Pada hukum keterbalikan kuadrat diperoleh intensitas cahaya dan iluminasi yang berbanding terbalik terhadap kuadrat jaraknya.

Percobaan kedua dilakukan dengan variasi daya pada $L_{1 B}=25$ watt dan
$\mathrm{L}_{2 \mathrm{~B}}=25$ watt. Titik semi transparan diperoleh untuk kedua buah lampu, yaitu sebesar $45 \mathrm{~cm}$. Batas minimumnya sebesar $35 \mathrm{~cm}$ dan batas maksimumnya sebesar $55 \mathrm{~cm}$. Oleh karena itu, diperoleh data percobaan seperti pada tabel 4, berikut:

Tabel 4. Jarak (x) dan Iluminasi $(E)$

\begin{tabular}{cccc}
\hline \multirow{2}{*}{ No. } & \multirow{2}{*}{ Jarak (cm) } & \multicolumn{2}{c}{ Iluminasi $(\boldsymbol{E})$} \\
\cline { 3 - 4 } & & $\mathbf{L}_{\mathbf{1 B}}$ & $\mathbf{L}_{\mathbf{2 B}}$ \\
\hline 1. & 35 & 72,60602 & 37,90859 \\
2. & 40 & 56,96274 & 40,61093 \\
3. & 45 & 48,34472 & 44,24663 \\
4. & 50 & 41,9043 & 48,88896 \\
5. & 55 & 36,79246 & 52,8975 \\
\hline
\end{tabular}

Setelah diketahui nilai iluminasi kurva pada kedua sumber cahaya, pada dua buah sumber cahaya lampu, seperti pada gambar 3 berikut: selanjutnya ditentukan titik potong

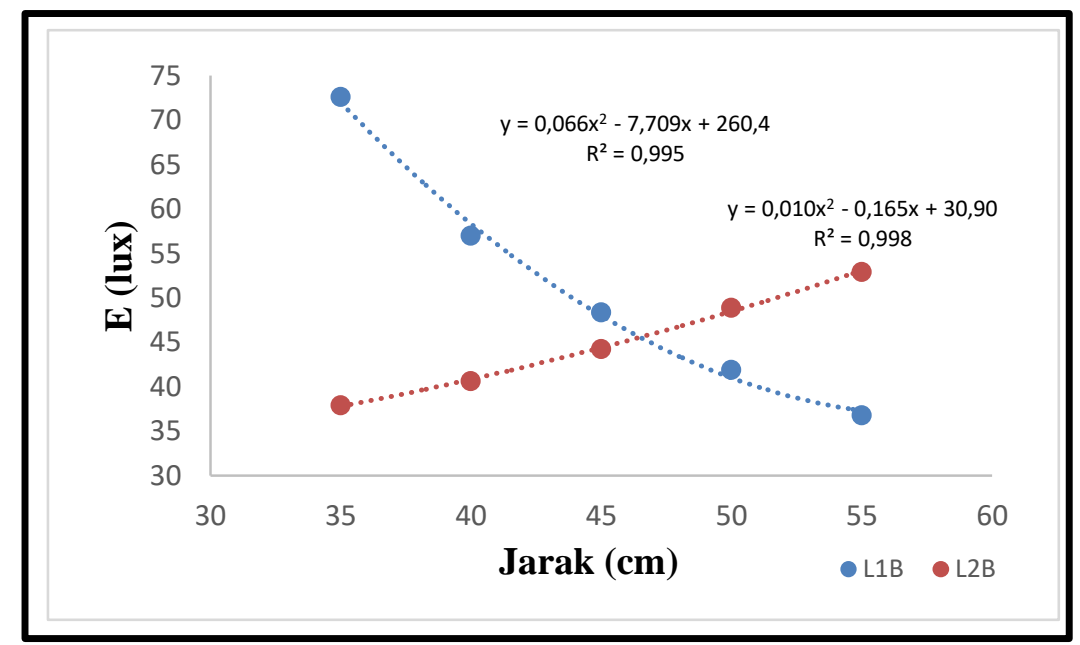

Gambar 3. Hubungan Jarak dan Iluminasi 
Kurniawan., Pramudya. - Pengukuran Penjumlahan Intensitas ...

Prsamaan (3) dan (4) digunakan untuk menemukan titik semi transparan pada lightmeter, sehingga diperoleh $x=48,91063 \mathrm{~cm}$. Selisih pada kertas lightmeter dan photometer adalah $3,1063 \mathrm{~cm}$.
Sedangkan persamaan (5) dan (6) digunakan pada hukum keterbalikan kuadrat, digunakan untuk memperoleh intensitas cahaya dan iluminasi. Hasil perolehan intensitas cahaya dan iluminasi pada $\mathrm{L}_{1 \mathrm{~B}}$ dan $\mathrm{L}_{2 \mathrm{~B}}$, seperti pada tabel 5 berikut:

Tabel 5. Intensitas Cahaya (I) dan Iluminasi $(E)$

\begin{tabular}{cccccc}
\hline \multirow{2}{*}{ No. } & \multirow{2}{*}{$\mathbf{r}^{\mathbf{2}}(\mathbf{m})$} & \multicolumn{2}{c}{ Intensitas Cahaya $(\boldsymbol{I})$} & \multicolumn{2}{c}{ Iluminasi $(\boldsymbol{E})$} \\
\cline { 3 - 6 } & & $\mathbf{L}_{\mathbf{1 B}}$ & $\mathbf{L}_{\mathbf{2 B}}$ & $\mathbf{L}_{\mathbf{1 B}}$ & $\mathbf{L}_{\mathbf{2 B}}$ \\
\hline 1. & 0,1225 & 8,894237 & 4,643802 & 72,60602 & 37,90859 \\
2. & 0,16 & 9,114039 & 6,497749 & 56,96274 & 40,61093 \\
3. & 0,2025 & 9,789806 & 8,959942 & 48,34472 & 44,24663 \\
4. & 0,25 & 10,47608 & 12,22224 & 41,9043 & 48,88896 \\
5. & 0,3025 & 11,12972 & 16,00149 & 36,79246 & 52,8975 \\
\hline \multicolumn{2}{c}{ Rata-rata } & $\mathbf{6 , 2 7 4 6}$ & $\mathbf{9 , 8 8 0 8}$ & $\mathbf{9 , 6 6 5 0}$ & $\mathbf{5 1 , 3 2 2 0}$
\end{tabular}

Tabel 5 menunjukkan perolehan nilai intensitas cahaya dan iluminasinya. Pada hukum keterbalikan kuadrat diperoleh intensitas cahaya dan iluminasi yang berbanding terbalik terhadap kuadrat jaraknya.

Percobaan ketiga dilakukan dengan variasi daya pada $\mathrm{L}_{1 \mathrm{C}}=25$

Tabel 6. Jarak $(x)$ dan Iluminasi $(E)$

\begin{tabular}{cccc}
\hline \multirow{2}{*}{ No. } & \multirow{2}{*}{ Jarak (cm) } & \multicolumn{2}{c}{ Iluminasi $(\boldsymbol{E})$} \\
\cline { 3 - 4 } & & $\mathbf{L}_{\mathbf{1 C}}$ & $\mathbf{L}_{\mathbf{2 C}}$ \\
\hline 1. & 45 & 58,541015 & 29,41923 \\
2. & 50 & 49,69246833 & 32,24427 \\
3. & 55 & 41,982805 & 35,70419 \\
4. & 60 & 36,74079167 & 40,83608 \\
5. & 65 & 33,0101 & 47,54389 \\
\hline
\end{tabular}


Kurniawan., Pramudya. - Pengukuran Penjumlahan Intensitas...

Setelah diketahui nilai iluminasi kurva pada kedua sumber cahaya, pada dua buah sumber cahaya lampu. seperti pada gambar 4 berikut: Selanjutnya ditentukan titik potong

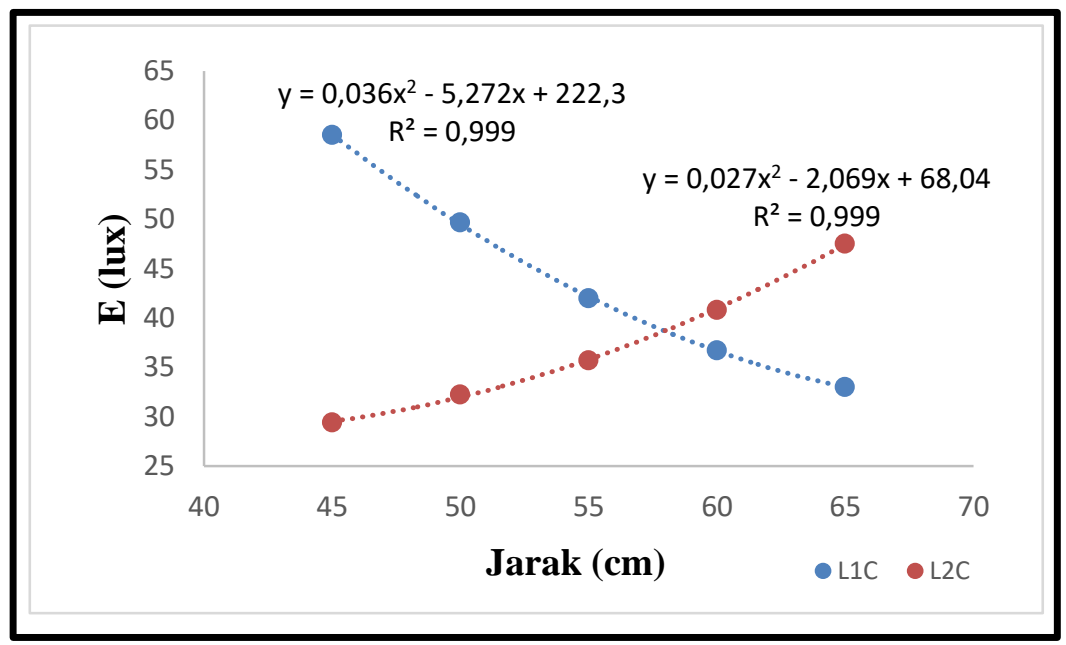

Gambar 4. Hubungan Jarak dan Iluminasi

Persamaan (3) dan (4) digunakan perolehan intensitas cahaya dan untuk menemukan titik tengah iluminasi pada $\mathrm{L}_{1 \mathrm{C}}$ dan $\mathrm{L}_{2 \mathrm{C}}$, seperti intensitas pada lightmeter, sehingga pada tabel 7 yang menunjukan diperoleh $x=57,91692 \mathrm{~cm}$. Selisih perolehan nilai intensitas cahaya dan pada kertas lightmeter dan iluminasinya. Pada hukum photometer adalah 2,91692 cm. keterbalikan kuadrat intensitas

Persamaan (5) dan (6) digunakan diperoleh intensitas cahaya dan pada hukum keterbalikan kuadrat, iluminasi yang berbanding terbalik digunakan untuk memperoleh terhadap kuadrat jarak. intensitas cahaya dan iluminasi. Hasil

Tabel 7. Intensitas Cahaya $(I)$ dan Iluminasi $(E)$

\begin{tabular}{cccccc}
\hline \multirow{2}{*}{ No. } & \multirow{2}{*}{$\mathbf{r}^{2}(\mathbf{m})$} & \multicolumn{2}{c}{ Intensitas Cahaya $(\boldsymbol{I})$} & \multicolumn{2}{c}{ Iluminasi $(\boldsymbol{E})$} \\
\cline { 3 - 6 } & & $\mathbf{L}_{\mathbf{1 C}}$ & $\mathbf{L}_{\mathbf{2 C}}$ & $\mathbf{L}_{\mathbf{1 C}}$ & $\mathbf{L}_{\mathbf{2 C}}$ \\
\hline 1. & 0,2025 & 11,85456 & 5,957394 & 58,54102 & 29,41923 \\
2. & 0,25 & 12,42312 & 8,061067 & 49,69247 & 32,24427 \\
3. & 0,3025 & 12,6998 & 10,80052 & 41,98281 & 35,70419 \\
4. & 0,36 & 13,22669 & 14,70099 & 36,74079 & 40,83608 \\
5. & 0,4225 & 13,94677 & 20,08729 & 33,0101 & 47,54389 \\
\hline \multicolumn{2}{r}{ Rata-rata } & $\mathbf{6 , 2 7 4 6}$ & $\mathbf{1 2 , 8 3 0 2}$ & $\mathbf{1 1 , 9 2 1 5}$ & $\mathbf{4 3 , 9 9 3 4}$ \\
\hline
\end{tabular}


Kurniawan., Pramudya. - Pengukuran Penjumlahan Intensitas...

\section{Pembahasan}

Data intensitas cahaya diperoleh dari hasil pencarian data awal berupa iluminasi. Pengambilan data ini dilaksanakan pada tiga buah variasi daya lampu. Setiap variasi dilakukan pengambilan data berupa jarak transparan menggunakan photometer. Selanjutnya iluminasi diperoleh melalui lightmeter yang tampilkan di gambar 2.

Titik semi transparan ini merupakan titik dimana noktah minyak pada kertas menghilang. Sehingga diperoleh hasil titik semi transparan yang ditampilkan pada tabel 1. Jarak titik yang telah ditentukan pada variasi pertama dan kedua adalah $35 \mathrm{~cm}-55 \mathrm{~cm}$. Pada variasi ketiga jarak yang dipergunakan untuk mengukur iluminasi adalah 45 $\mathrm{cm}-65 \mathrm{~cm}$. Pengukuran iluminasi dilakukan menggunakan lightmeter pada smartphone. Hubungan iluminasi dan jarak ditampilkan pada tabel 2, 4, dan 6. Posisi lightmeter pada jarak yang lebih jauh dari pusat cahaya membuat iluminasi semakin kecil (Irwanto \& Setiabudi, 2017).

Kertas photometer yang terdapat noktah minyak ditengahnya akan menjadi transparan pada jarak tertentu. Hal ini dilakukan ketika kedua sumber daya dinyalakan untuk ketiga variasinnya. Iluminasi pada kedua sumber cahaya saling berhubungan untuk masing-masing variasi seperti pada gambar 2, 3, dan 4. Terdapat titik potong kurva antara kedua sumber cahaya. Titik potong kurva ini melalui persamaan (3) dan (4) digunakan untuk jarak titik semi transparan dari lightmeter. Oleh karena itu, titik semi transparan yang diperoleh menggunakan lightmeter dan photometer, seperti pada tabel 8 berikut:

Tabel 8. Titik Semi Transparan

\begin{tabular}{cccc}
\hline No. & Lightmeter $\mathbf{( c m )}$ & Photometer $(\mathbf{c m})$ & Selisih $(\mathbf{c m})$ \\
\hline 1. & 48,1193 & 45 & 3,1193 \\
2. & 48,9106 & 45 & 3,1063 \\
3. & 57,9169 & 55 & 2,9169 \\
\hline
\end{tabular}

Hasil tersebut menunjukan bahwa selisih titik semi transparan dari kedua alat ukur tidak terlalu jauh. Ketika pengukuran dilakukan kembali dengan 
Kurniawan., Pramudya. - Pengukuran Penjumlahan Intensitas ...

photometer, menggunakan titik dari lightmeter. Maka noktah berminyak akan menjadi semi transparan dengan lebih akurat.

Setelah diketahui nilai iluminasi dan jarak dari ketiga variasi. Persamaan (5) dan (6) dapat digunakan untuk menghitung intensitas cahaya dan iluminasi untuk setiap variasi. Hasil intensitas cahaya dan iluminasi yang ditemukan dapat dilihat pada tabel 3, 5, dan 7. Iluminasi berbanding lurus intensitas cahaya dan berbanding terbalik dengan kuadrat jarak. Hal ini sesuai dengan hukum keterbalikan kuadrat pada hukum fisika yang menyatakan sumber pancaran berbanding terbalik dengan jaraknya (Kumorowati et al., 2016).

\section{KESIMPULAN DAN SARAN}

\section{Kesimpulan}

Intensitas cahaya pada dua sumber cahaya, memiliki hasil yang berbanding lurus dengan iluminasinya. Hal ini terjadi untuk setiap variasi lampu yang digunakan. Kemudian iluminasi dan intensitas cahaya berbanding terbalik dengan kuadrat jaraknya. Oleh karena itu, semakin besar jarak lightmeter yang digunakan, hasil yang diperoleh akan semakin kecil. Jika semakin kecil jaraknya, maka hasilnya akan semakin besar. Hal ini termasuk untuk seluruh variasinya.

\section{Saran}

Diharapkan agar ke depannya dapat dikembangkan penelitian serupa dengan menggunakan variasi daya yang berbeda. Penelitian juga dapat dikembangkan untuk bidang pendidikan.

\section{DAFTAR PUSTAKA}

Afriyani, Septi, Surantoro, \& Supurwoko. (2019, 18 Desember). Development of the luminous intensity experiment tool using Excel spreadsheet to display data. AIP Conference Proceedings, AIP Publishing LLC, 2194, 1. https://doi.org/10.1063/1.5139733

Gutierrez, M, J, M., Castillo, M, A., Medina, M, J. A., Aguado, D, J., \& Martinez, H, J. J. (2017). Smartphones as a light measurement tool: Case of study. Applied Sciences, 7(6), 1-18. https://doi.org/10.3390/app706061 $\underline{6}$

Hasanah, N., \& Nurdiawati, D. (2017).

Analisa PengukuranIluminasi Penerangan Lampu Fl pada Ruang Perkuliahan. Jurnal Sains dan Teknologi, 7(2), 1-7. https://unsada.ejournal.id/jst/articl e/view/24 
Kurniawan., Pramudya. - Pengukuran Penjumlahan Intensitas ...

Herdiwijaya,

D. $(2016, \quad 14-15$

Desember).

Pengukuran

Kecerahan Langit Malam Arah

Zenit Untuk Penentuan Awal

Waktu Fajar. Prosiding SKF, 2016, 95-102.

https://ifory.id/abstract/nNBW8p9

$\underline{\mathrm{RAaE} 2}$

Irwanto, E., \& Setiabudi, M. A. (2017). Pengaruh Penempatan Jarak Titik Lampu dan Kombinasi Warna Terhadap Perubahan Kondisi Lingkungan Lapangan Indoor Bulutangkis. Jorpres (Jurnal Olahraga Prestasi), 13(2), 128-138.

https://doi.org/10.21831/jorpres.v $\underline{13 \mathrm{i} 2.25106}$

Kumorowati, B., Masturi., Yulianti, I., Rahman, F.A. (2016). Analisis Reduksi Intensitas Cahaya Pada Smartphones' Screen Protector Dan Dampaknya Pada Mata. JIPF (Jurnal Ilmu Pendidikan Fisika), 1(1), 1-4.

http://dx.doi.org/10.26737/jipf.v1i $\underline{1.51}$

Nurfarida, L., Yusup, P. M., \& Komariah, N. (2017). Tingkat PengetahuanMasyarakat Sekitar Observatorium Bosscha Lembang Mengenai Polusi Cahaya. Jurnal Kajian Informasi \& Perpustakaan, 5(1), 13-22.

https://doi.org/10.24198/jkip.v5i1. $\underline{11327}$

Rahmadiansyah, A., Orlanda, E., Wijaya, M., Nugroho, H. W., \& Firmansyah, R. (2017). Perancangan Sistem Telemetri Untuk Mengukur Intensitas Cahaya Berbasis Sensor Light Dependent Resistor Dan Arduino Uno. Journal of Electrical and
Electronics Engineering

UMSIDA, 1(1), 15-21.

https://10.21070/jeee-u.v1i1.760

Rahman, R. (2016). Analisis Hasil Pengukuran Kuat Penerangan di Gedung Fisika FMIPA Universitas Cenderawasih. Sains: Jurnal MIPA dan Pengajarannya,16(2), 61-65, from https://ejournal.uncen.ac.id/index. php/SAINS/article/view/272/243

Saputra, D. A., \& Nurdiah, E, A. (2013). Perpustakaan Umum di Yogyakarta dengan Pendalaman Desain Pencahayaan. eDimensi Arsitektur Petra, 1(1), 1-5, from http://publication.petra.ac.id/index .php/teknikarsitektur/article/view/ 331/271

Sudin, N., Djufri, I., \& Umar, M. K. G. (2020). Rancang Bangun Sistem Pengontrol Lampu Rumah Berbasis Mikrokontroler Arduino Uno Menggunakan Smartphone. Jurnal Ilmiah ILKOMINFO-Ilmu Komputer \& Informatika, 3(2), 52-61.

https://doi.org/10.47324/ilkominfo .$v 3 \mathrm{i} 2.102$

Sukmawati, S. S., \& Pramudya, Y. (2019, 14 November). Light Intensity Measurement On SunEarth System Model Using Logger Pro Light Sensor. In Journal of Physics: Conference Series (Vol. 1254, No. 1, p. 012067). IOP Publishing.

https://iopscience.iop.org/article/1 $\underline{0.1088 / 1742-6596 / 1254 / 1 / 012067}$

WU, Pei-Chang, et al (2018). Myopia Prevention and Outdoor Light Intensity in a School-Based Cluster Randomized Trial. Ophthalmology, 125(8), 1239- 
Kurniawan., Pramudya. - Pengukuran Penjumlahan Intensitas ...

1250.

https://doi.org/10.1016/j.ophtha.2 $\underline{017.12 .011}$

Zelviani, S., \& Albar, A. (2018).

Hubungan Intensitas Cahaya dan

Jarak Pancaran Sebagai Hukum
Kebalikan Kuadrat. JFT: Jurnal Fisika dan Terapannya, 5 (1), 710.

https://doi.org/10.24252/jft.v5i1.1 5927 